\title{
On the rarity of anterior teeth of Asteracanthus magnus (Euselachii; Hybodontiformes)
}

\author{
Stanislas Rigal and Gilles Cuny
}

LGLTPE, UMR CNRS ENS 5276, Université Claude Bernard Lyon 1, Campus de la Doua, Bâtiment Géode, 2, rue Raphaël Dubois, F-69622 Villeurbanne Cedex, France

\begin{abstract}
A partial dentition found in the Middle Jurassic (Bathonian) of Normandy (France) associates lateral teeth of Asteracanthus magnus with anterior teeth usually attributed to $A$. tenuis or A. longidens. According to this French specimen, teeth usually identified as anterior of $A$. magnus represent in fact teeth of the first lateral file. This discovery explains the apparent rarity of isolated anterior teeth of A. magnus in the fossil record, for which no associated dentition were hitherto known. It also demonstrates that the general arrangement of the dentition of $A$. magnus is closer to the one of A. smithwoodwardi than to the one of $A$. medius.
\end{abstract}

Key words: Asteracanthus, dentition, Jurassic, Bathonian, France.

\section{Introduction}

The genus Asteracanthus was erected by Agassiz in 1837 based on dorsal fin-spines found in the Upper Jurassic of England that he attributed to A. ornatissimus (AGASSIZ 1833-44, vol. 3, p. 31). In the same work, this author also erected the genus Strophodus, which he thought was closely related to Acrodus, based on a partial dentition found in the Bathonian of France, which he attributed to S. longidens (AGASSIZ 1833-44, vol. 3, p. 117). The latter was, however, destroyed during the bombing of the Caen Museum by the Allied in July 1944 (BIGOT 1945). The discovery of teeth of Strophodus associated with fin-spines of the type species of Asteracanthus, A. ornatissimus, represented the first piece of evidence that the teeth and finspines could represent in fact a single animal (WOODWARD 1888). The apparent synonymy between the two genera is, however, not so simple as recently demonstrated by REES \& UNDERWOOD (2008), who erected a new genus, Frangerodus, for the teeth of Strophodus lingualis. No dorsal fin-spines have so far been associated with this new genus.

Frangerodus appears to be less heterodont than Asteracanthus, but the heterodonty pattern of the latter genus is not always fully understood. It has been suggested, for example, that one species of Asteracanthus, A. magnus, a species known from the Bathonian of England and France, might have possessed a single file of anterior teeth although most Jurassic species possess two files (REES \& UNDERWOOD 2008). We report here a partial dentition of $A$. magnus from the Bathonian of Normandy, which allows a better understanding of the heterodonty pattern in this species.

\section{Material and methods}

The described sample (MPV.2010.3.44) shows 54 teeth included into a piece of Bathonian Calcaire de Caen measuring $19 \times 12 \times 11 \mathrm{~cm}$ (Fig. 1). MPV.2010.3.44 was purchased by the Paléospace, palaeontological museum of Villers-sur-Mer (MPV) during the auction of the Folet collection, a local avocational palaeontologist, at Saint Valery en Caux (Normandy) on January $3^{\text {rd }}, 2010$. It was extracted from a quarry in the vicinity of the city of Caen, although the exact location was not provided and remains unknown as many quarries in the area have been closed down and are no longer accessible. 
Although the dentition is not fully articulated, several groups of teeth are in connection. Together with the fact that the porous and fragile roots of the teeth are perfectly preserved, it indicates that these teeth belonged to a single individual.

All measurements were taken with callipers having an accuracy of $0.1 \mathrm{~mm}$. Pictures of the specimen were taken with a digital camera (Canon G11) in macro mode. The systematic scheme used here follows REES \& UNDERWOOD (2008) and descriptive terminology follows CAPPETTA (2012), more particularly concerning the definition of "rows" and "files". The use of the term 'root' also follows CAPPETTA (2012), but does not imply direct homology with the root of the teeth of other gnathostomes (UNDERWOOD et al. 2015).

\title{
3. Geological settings
}

The Calcaire de Caen Formation is dated from the beginning of the Middle Bathonian (DUGUÉ et al. 1998). It is made of an homogeneous, fine-grained biomicrite, and its environment of deposition is considered as a low-energy, subtidal one (DUGUÉ et al. 1998). This formation is well-known for its fossils of crocodiles and dinosaurs that have been described during the $19^{\text {th }}$ Century by Cuvier, Geoffroy-Saint-Hilaire and EudesDeslongchamps (BUFFETAUT 2008).

\section{Systematic palaeontology}

\author{
Class Chondrichthyes HuXLEY, 1880 \\ Cohort Euselachii HAY, 1902 \\ Order Hybodontiformes PATTERSON, 1966 \\ Family Hybodontidae OwEN, 1846 \\ Subfamily Acrodontinae CASIER, 1959 sensu MAISEY, 1989 \\ Genus Asteracanthus AgASSIZ, 1837 \\ Asteracanthus magnus (AGASSIZ, 1838)
}

Description: The dentition MPV.2010.3.44 includes 54 teeth, which have been subdivided into six files: symphyseal, first anterior, second anterior, first lateral, second lateral and posterior ones (Fig. 2). Anterior and symphyseal teeth are arched in labial or lingual view and show enlarged foramina concentrating in the centre of the lower part of the root in lingual view, whereas lateral teeth are flattened with roots less deep than in the anterior teeth.

Insert Fig. 2 near here

Four teeth identified as potential symphyseal ones are strongly arched in lingual view (Fig. 2.1). The crown is symmetric mesio-distally and shows a reticulated ornamentation as well as a longitudinal crest, which is worn out at the apex of the crown. The mesial, distal, labial and lingual faces are ornamented with irregular vertical ridges, more or less developed. The crown is separated from the root by a shallow groove and overhangs it. The root is at least twice the height of the crown. It shows randomly distributed foramina, with larger ones concentrating in the centre of its lower part in lingual view. 
Nine teeth identified as belonging to the first anterior file are also strongly arched in labial or lingual view, but their crowns are asymmetric, the distal part being more elongated and tapered than the mesial one (Fig. 2.2). The distal part is also curved lingually. The ornamentation is reticulated and a longitudinal crest is present, although it tends to disappear on the mesial part of the crown. The ornamentation of the mesial, distal, labial and lingual faces is similar to that of the symphyseal teeth. The crown is separated from the root by a shallow groove and overhangs it. The root has a structure similar to that of the symphyseal tooth.

Twelve teeth identified as belonging to the second anterior file are less arched in labial or lingual views than those of the first anterior file (Fig. 2.3). Apart from that, their asymmetric crown is quite similar to the one of the teeth of the first anterior file. Two teeth in connection show that this shape allowed a tight interlocking between teeth of the same family. The ornamentation of the crown is reticulated, but the longitudinal crest is either absent or restricted to the distal part of the crown. The ornamentation of the mesial, distal, labial and lingual faces is similar to that of the preceding teeth. The crown is separated from the root by a shallow groove and overhangs it. In labial view, the root is divided in two halves by a vertical crest. Large foramina tend to concentrate on its distal half.

Nine teeth identified as belonging to the first lateral file are twice as large as the anterior ones (Table 1, fig. 2.4). In apical view, the crown shows a labial projection so that its outline is nearly triangular. Its ornamentation is reticulated, without a longitudinal crest. The base of the crown, as well as that of the root is nearly flat. The crown is separated from the root by a groove and overhangs it. The root is higher than the crown, but contrary to what is observed in anterior teeth, it never exceeds twice the height of the crown. The root, like the crown, shows a labial projection, better developed in its upper than in its lower part. Large foramina are scattered in the lower part of the root.

Insert Table 1 near here

Eleven teeth identified as belonging to the second lateral file are twice as large as those of the first lateral one (Fig. 2.5). The crown has a rhomboid, almost rectangular, outline in apical view. The ornamentation is reticulated, and often quite worn out on the apical face, whereas the mesial, labial, distal and lingual ones are smooth. Teeth identified as belonging to the lower dentition, see below, are narrower labio-lingually than the ones belonging to the upper dentition (Table 1). The crown is separated from the root by a groove. The root has a rather quadrangular shape and is projected distally. Large foramina are roughly aligned in the middle part of the root.

Nine teeth identified as belonging to the posterior file show a flat, oval-shaped crown, which is slightly compressed mesio-distally (Fig. 2.6). Its ornamentation is coarser than on the anterior and lateral teeth and is made of numerous small anastomosing ridges. The mesial, labial, distal and lingual sides of the crown are smooth. The root is quadrangular in shape with a flat base and is projected lingually. It is at least twice as high as the crown and twice as long labio-lingually. The root is also projected distally. In apical view, the distal projection is separated from the crown by a groove. The labial and lingual faces of the root are oblique so that there is an efficient interlocking between teeth of the same family as demonstrated by teeth still in connection. The root is devoid of enlarged foramina.

\section{Discussion}

\subsection{Reconstruction of the dentition}


Two sets of two second lateral teeth in connection, one with a slightly concave surface (Fig. 3, LUSL), the other with a slightly convex surface (Fig. 3, LLSL), appear to have been in occlusion, indicating that MPV.2010.3.44 encompasses teeth belonging to the lower and upper jaws. If we compare with Agassiz's description of Asteracanthus (Strophodus) longidens, the convex teeth are likely to belong to the lower jaw, whereas the slightly concave ones belong to the upper jaw (AGASSIZ1833-44, vol. 3, p. 122). The two upper second lateral teeth appear to be in connection with two first lateral (Fig. 3, LUFL), two second anterior (Fig. 3, LUSA) and one first anterior ones (Fig. 3, LUFA). These seven teeth belong to the left part of the upper dentition. Its right part is probably represented by four second lateral teeth, one devoid of crown and one with the crown partly lacking, located on the other side of MPV.2010.3.44 (Fig. 3, RUSL). All their crowns are slightly concave and they appear to belong to the same file. At least four teeth in a file are congruent with the seven teeth per file observed in A. medius by OWEN (1869). These four teeth are still in connection with a first lateral tooth (Fig. 3, RUFL). Five posterior teeth, three of which still in connection, located in the middle part of MPV.2010.3.44 between the left and right upper part of the dentition are therefore likely to belong to the lower jaws (Fig. 3, LP), the lower dentition having slid on the upper one. Apparently, the lower dentition was quite scattered around during the sliding, so that no connection between teeth of different files was preserved. As there is a mixing between lower and upper teeth in the central part of MPV.2010.3.44, it is quite difficult to ascertain whether the anterior and lateral teeth present in this area belong to the lower or upper jaws. The same is true of the symphyseal teeth recovered (Fig. 3, S), which are also located in this area.

Insert Fig. 3 near here

When describing the lower jaw of Asteracantus medius, OwEN (1869) noticed that it did not possess a symphyseal file, like in the modern Heterodontus. However, comparisons with this genus seems to be quite hazardous, as different species might have various dental patterns. Indeed, several authors attributed a symphyseal file either on only one jaw (lower jaw of Heterodontus portusjacksoni in PFEIL (2010)) or on both jaws (REIF (1976). Woodward, on the other hand, associated the symphyseal file of Asteracanthus ornatissimus with the lower jaw (WoODWARD 1888), as did PFEIL (2010). MPV.2010.3.44 does not allow deciding on which jaw it is the most likely that symphyseal teeth were present.

The distal projection of the root of the posterior teeth seems to indicate that MPV.2010.3.44 possessed a single file of posterior teeth, at least on the lower jaw, like the Liassic species A. smithwoodwardi from Switzerland (PEYER 1946) although most Middle Jurassic species possessed two files (REES \& UNDERWOOD 2008). The general dental formula of MPV.2010.3.44 is therefore likely to be S-A1-A2-L1-L2-P for the lower jaw and A1-A2L1-L2-P for the upper jaw.

\subsection{Comparisons}

Compared with A. tenuis and A. longidens, MPV.2010.3.44 possess less elongated lateral teeth, without a dome and its ornamentation pattern is very different from the one of $A$. ornatissimus (REES \& UNDERWOOD 2008). On the other hand, the shape and ornamentation pattern of the teeth of MPV.2010. 3.44 belonging to the second lateral file are very similar to those of A. magnus (AGASSIZ 1833-44, REES \& UNDERWOOD 2008). However, the anterior teeth of MPV.2010.3.44 are more arched than the ones usually attributed to the latter species and are more reminiscent of anterior teeth of A. tenuis or A. longidens (REES \& UNDERWOOD 
2008). The tooth P.66481 from the collection of the Natural History Museum, London, identified by REES \& UNDERWOOD (2008, pl. 5, figs. 1-2) as an anterior tooth of A. magnus is strikingly similar to the teeth of MPV.2010.3.44 interpreted here as belonging to the first lateral file. They share the same ornamentation pattern and a flat crown with a triangular outline. First lateral teeth with a similar outline were also illustrated for A. subreticulatus by AgASSIZ (1833-44) and OPPENHEIMER (1907) and in A. smithwoodwardi by PEYER (1946). A. subreticulatus was considered a junior synonym of $A$. ornatissimus by WOODWARD (1889). We therefore conclude that P.6648 was misidentified as an anterior tooth and represents in fact a first lateral one, leaving the species A. magnus without identified anterior teeth. As there is a single file of first lateral teeth, and not two as for anterior teeth, this explains the apparent rarity of this kind of teeth as noted by REES \& UNDERWOOD (2008) in the collection of the Natural History Museum in London.

REES \& UNDERWOOD (2008) considered A. magnus and A. medius as belonging to the same group based on the following characters: "Teeth with a weak reticulate ornamentation and a dentition with wide, rectangular lateral teeth and weakly arched anterior teeth".

MPV.2010.3.44 shows that in fact A. magnus is quite different from A. medius based on the following characters: presence of strongly arched anterior teeth, first lateral teeth much shorter mesio-distally than the second lateral ones (They have approximately the same length in A. medius) and the presence of a single file of posterior teeth. All in all, the general pattern of the dentition of A. magnus is much closer to A. smithwoodwardi than to A. medius.

PFEIL (2010) described an Asteracanthus dentition of BSPG 2010 I 91 from the Tithonian of South-West Germany, where the symphyseal, anterior and first lateral teeth (symphyseal, anterior and anterio-lateral in PFEIL (2010)) are very similar to those of MPV.2010.3.44. However, the shape and the size of both second lateral (lateral in PFEIL (2010)) and posterior teeth are fairly different from those of MPV.2010.3.44. The distal edge of the second laterals of (BSPG 2010 I 91) has a blunt tip and are smaller and less elongated (mesio-distal length: $23 \mathrm{~mm}$, labio-lingual width: $17 \mathrm{~mm}$ ). The posterior teeth have a more elongated (mesio-distal length: $7 \mathrm{~mm}$, labio-lingual width: $20 \mathrm{~mm}$ ) and more angular shape.

\section{Conclusion}

MPV.2010.3.44 represents the first discovery of a dentition of A. magnus partly in connection and allows a complete reappraisal of the dentition pattern of this species. Its first lateral teeth were misidentified as anterior ones and the latter were probably not recognized as such and attributed to A. tenuis or A. longidens because anterior teeth of these three species are quite similar. This explains the apparent rarity of $A$. magnus anterior teeth in the collection of the Natural History Museum, London noted by REES \& UNDERWOOD (2008). The arrangement of the dentition of A. magnus appears quite different from the one of A. medius and is more reminiscent of what can be observed in the older A. smithwoodwardi.

\section{Acknowledgements}

We are thankful to Laurent Picot (Paléospace, Villers-sur-Mer) who put MPV.2010.3.44 at our disposal for study and to Charlie Underwood for useful discussion. Sarah Rigal provided us with hard-to-find references. We also thank to our two reviewers, Friedrich Pfeil and Jürgen Kriwet, who help us to improve the manuscript. This work was supported by UMR 5276. 


\section{References}

Agassiz, J. L. R. (1833-1844): Recherches sur les poissons fossiles vol. 3. - VIII+390+32 pp.; Neuchâtel (Imprimerie de Petitpierre).

Bigot, A. (1945): La destruction des collections et des bibliothèques scientifiques de Caen. Bulletin de la Société linnéenne de Normandie, supplementary volume: 1-75.

BuffetAut, E. (2008): À l'aube de la paléontologie des Vertébrés : Cuvier, Geoffroy SaintHilaire et les « gavials » de Honfleur, du Havre et de Caen. Bulletin de la Société Géologique de normandie et des Amis du Muséum du Havre, 95(2): 153-162.

CAPPETTA, H. (2012): Chondrichthyes Mesozoic and Cenozoic Elasmobranchii: Teeth (Handbook of Paleoichthyology vol. 3E). - München (Dr. Friedrich Pfeil).

CASIER, E. (1959): Contributions à l'étude des Poissons fossiles de la Belgique. XII. Sélaciens et Holocephales sinémuriens de la province de Luxembourg. Bulletin de l'Institut Royal des Sciences Naturelles de Belgique, 35: 1-27.

Dugué, O., Fily, G., \& Rioult, M. (1998): Le Jurassique des côtes du Calvados. - Bulletin Trimestriel de la Société Géologique de Normandie et des Amis du Muséum du Havre, 85: $1-132$.

HAY, O.P. (1902): Bibliography and catalogue of the fossil vertebrate of North America. Bulletin of the United States Geological Survey, 179: 1-868.

HuXLEY, T.H. (1880): On the application of the Laws of Evolution to the Arrangement of the Vertebrata, and more particularly of the Mammalia. - Proceedings of the Zoological Society, 1880: 649-662.

MAISEY, J.G. (1989): Hamiltonichthys mapesi, g. and sp. nov. (Chondrichthyes; Elasmobranchii), from the Upper Pennsylvanian of Kansas. - American Museum Novitates, 2931: 1-42.

OPPENHEIMER, J. (1907): Der Malm der Schwedenschanze bei Brunn. - Beiträge für Paleontologie und Geologie des Österrreich und des Ungarns, Orients 20: 221-256.

OWEN, R. (1846): Lectures on the comparative anatomy and physiology of the vertebrate animals, delivered at the RoyalCollege of Surgeons of England in 1844 and 1846. Part1. Fishes. London (Longman, Brown, Green \& Longmans).

OWEN, R. (1869): Description of a great part of a Jaw with the Teeth of Strophodus medius, Ow., from the Oolite of Caen in Normandy. - Geological Magazine, 6: 193-196.

PATTERSON, C. (1966): British Wealden sharks. - Bulletin of the British Museum (Natural History), Geology, 11: 283-350.

PEYER, B. (1946): Die schweizerischen Funde von Asteracanthus (Strophodus). -

Schweizerische Paläontologische Abhandlungen, 64: 1-56.

PfeIL, F. H., (2010): Ein neues Asteracanthus-Gebiss aus den Kieselplattenkalken (Oberjura, Tithonium, Malm Zeta 3, Mörnsheim-Formation) des Besuchersteinbruchs in Mühlheim. - Jahresbericht 2010 und Mitteilungen. Der Freunde der Bayerischen. Staatssammlung für Paläontolgie und Historische Geologie München e.V., 39: 36-60.

REES, J., \& UNDERWOOD, C. J. (2008): Hybodont sharks of the English Bathonian and Callovian (Middle Jurassic). - Palaeontology, 51: 117-147.

REIF, W.-E., (1976): Morphogenesis, pattern formation and function of the dentition of Heterodontus. - Zoomorphologie, 83: 1-47.

Underwood, C.J., Johanson, Z., Welten, M., Metscher, B., RAsCh, L.J., Fraser, G.J., \& SMITH, M.M. (2015): Development and evolution of dentition pattern and tooth order in the skates and rays (Batoidea; Chondrichthyes). - PLoS One, 10: 1-19.

WoODWARD, A. S. (1888): On some remains of the extinct Selachian Asteracanthus from the Oxford Clay of Peterborough, preserved in the collection of Alfed N. Leeds, Esq., of Eyebury. - The Annals and Magazine of Natural History ser. 6 vol. 2: 336-342. 
WoodwaRD, A. S. (1889): Catalogue of the fossil fishes in the British Museum (Natural History) (Part 1 containing the Elasmobranchii). - 567 pp.; London (Printed by order of the Trustees). 
Table

\begin{tabular}{|c|c|c|c|c|c|c|}
\hline Number & Symphyseal & $\begin{array}{l}9 \\
2 \text { of them } \\
\text { worn }\end{array}$ & $\begin{array}{l}\text { Second } \\
\text { Anterior } \\
12 \\
3 \text { of them } \\
\text { worn }\end{array}$ & $\begin{array}{l}9 \\
4 \text { of them } \\
\text { worn }\end{array}$ & $\begin{array}{l}\text { Second } \\
\text { lateral } \\
11 \\
3 \text { of them } \\
\text { worn }\end{array}$ & Posterior \\
\hline $\begin{array}{l}\text { Maximal } \\
\text { basal } \\
\text { height }\end{array}$ & 7,2 & $\begin{array}{l}9,2 \\
\text { (average on } \\
8 \text { teeth }(8,7 \\
\text { to } 9,7))\end{array}$ & $\begin{array}{l}9 \\
\text { (average on } \\
5 \text { teeth }(8,8 \\
\text { to } 9,3))\end{array}$ & 8 & $\begin{array}{l}10,2 \text { (average } \\
\text { on } 3 \text { teeth } \\
(9,7 \text { to } 11))\end{array}$ & $\begin{array}{l}8,4 \\
\text { (average on } 6 \\
\text { teeth }(8,2 \text { to } \\
8,7))\end{array}$ \\
\hline $\begin{array}{l}\text { Maximal } \\
\text { coronary } \\
\text { height }\end{array}$ & 5,1 & $\begin{array}{l}4 \\
\text { (average on } \\
8 \text { teeth }(3,8 \\
\text { to } 4,2))\end{array}$ & $\begin{array}{l}3,6 \\
\text { (average on } \\
5 \text { teeth }(3,5 \\
\text { to } 3,8))\end{array}$ & 6,7 & $\begin{array}{l}6 \\
\text { (average on } 3 \\
\text { teeth }(5,7 \text { to } \\
6,, 2))\end{array}$ & $\begin{array}{l}2,7 \\
\text { (average on } 6 \\
\text { teeth }(2,5 \text { to } \\
3,1))\end{array}$ \\
\hline $\begin{array}{l}\text { Maximal } \\
\text { mesio- } \\
\text { distal } \\
\text { length }\end{array}$ & 15,4 & $\begin{array}{l}15,3 \\
\text { (average on } \\
8 \text { teeth }(14 \\
\text { to } 16))\end{array}$ & $\begin{array}{l}18,6 \\
\text { (average on } \\
7 \text { teeth }(17 \\
\text { to } 19,6))\end{array}$ & $\begin{array}{l}23,5 \\
\text { (average on } \\
5 \text { teeth } \\
(22,8 \text { to } \\
24) \text { ) }\end{array}$ & $\begin{array}{l}45,4 \text { (average } \\
\text { on } 4 \text { teeth } \\
(44,8 \text { to } \\
45,9))\end{array}$ & $\begin{array}{l}12,2 \text { (average } \\
\text { on } 3 \text { teeth } \\
(10,8 \text { to } \\
14,9))\end{array}$ \\
\hline $\begin{array}{l}\text { Maximal } \\
\text { labio- } \\
\text { lingual } \\
\text { length }\end{array}$ & 9,1 & $\begin{array}{l}8 \text { (average } \\
\text { on } 8 \text { teeth } \\
(7,8 \text { to } 8,1))\end{array}$ & $\begin{array}{l}8 \text { (average } \\
\text { on } 7 \text { teeth } \\
(7,5 \text { to } 8,5))\end{array}$ & $\begin{array}{l}14,5 \\
\text { (average on } \\
5 \text { teeth } \\
(14,2 \text { to } \\
14,8))\end{array}$ & $\begin{array}{l}\text { LT: } 18,9 \\
\text { (average on } 3 \\
\text { teeth }(18,7 \text { to } \\
19,2)) \\
\text { UT: } 20,8 \\
\text { (average on } 4 \\
\text { teeth }(20,4 \text { to } \\
21,3))\end{array}$ & $\begin{array}{l}\text { Base: } 13,5 \\
\text { (average on } 6 \\
\text { teeth }(12,1 \text { to } \\
16)) \\
\text { Crown: } 9,2 \\
\text { (average on } 6 \\
\text { teeth }(8 \text { to } \\
11,5) \text { ) }\end{array}$ \\
\hline
\end{tabular}

Table 1. Numbers and measurements of the different kind of teeth identified in MPV.2010.3.44. When possible, measurements were averaged and the smallest and the largest ones are given between brackets. LT: lower teeth, UT: upper teeth. All measurements are in $\mathrm{mm}$. 


\section{Figure captions}

Fig. 1. Photograph of MPV.2010.3.44. Not all the teeth are visible in this photograph. Numbers 1 to 6 refer to the teeth illustrated in Fig. 2.

Fig. 2. Illustrations of the six tooth types recognized in MPV.2010.3.44.

Fig. 3. Interpretation of the dentition of MPV.2010.3.44. LLSL: Left lower second lateral teeth, LP: Lower posterior teeth, LUFA: Left upper first anterior tooth, LUFL: Left upper first lateral teeth, LUSA: Left upper second anterior teeth, LUSL: Left upper second lateral teeth, RUFL: Right upper first lateral tooth, RUSL: Right upper second lateral teeth, S: Symphyseal tooth. 